\title{
Behaviour of aggregated grey nurse sharks Carcharias taurus off eastern Australia: similarities and differences among life-history stages and sites
}

\author{
Kirby R. Smith ${ }^{1, *}$, Carol Scarpaci ${ }^{1}$, Brett M. Louden ${ }^{2}$, Nicholas M. Otway ${ }^{2}$ \\ ${ }^{1}$ College of Engineering and Science, Victoria University, PO Box 14428, Melbourne, Victoria 8001, Australia \\ ${ }^{2}$ Port Stephens Fisheries Institute, New South Wales Department of Primary Industries, Locked Bag 1, Nelson Bay, \\ New South Wales 2315, Australia
}

\begin{abstract}
Stereo-video photogrammetry was used to document swimming and non-swimming behaviours of various life-history stages of the grey nurse shark Carcharias taurus at 8 east Australian aggregation sites (during daylight) in the absence of scuba diving tourism and fishers. Swimming behaviours included hovering, milling, and active swimming with significantly greater milling. Rates of movement were least during milling and greatest for active swimming. Pectoral fins were held 20 to $24^{\circ}$ below horizontal, which was consistent with holding positions reported in shark swimming studies. Significantly lower caudal fin positions during hovering probably minimised forward propulsion. Tail-beat frequency decreased significantly with increasing total length and was likely due to greater propulsion from larger caudal fins. Low activity indicated that sharks minimised energy expenditure when aggregated, which was associated with migratory and reproductive behaviours. Significantly different pectoral fin positions among sites likely resulted from differing navigational requirements. Non-swimming behaviours were infrequent. Chafing, gill puff, head snapping and palatoquadrate protrusion were generally categorised as grooming behaviour. One gill puff sequence and all but one rapid withdrawal event were categorised as 'flight'-response agonistic behaviour. The remaining rapid withdrawal and stand back were to avoid collision and categorised as swimming behaviour. The absence of 'fight'-response agonistic behaviour was consistent with previous descriptions of the species as docile. This partial ethogram will enhance ecological understanding, assist assessment and management of diving tourism, and contribute to the recovery and long-term conservation of this critically endangered species.
\end{abstract}

KEY WORDS: Shark - Carcharias taurus - Critically endangered · Ethogram · Stereo photogrammetry $\cdot$ Fin angles $\cdot$ Tail beats $\cdot$ Rates of movement

\section{INTRODUCTION}

An ethogram provides a descriptive account of behaviours exhibited by a species, and can be enhanced with quantitative analyses of the durations, frequencies and extent of events. Behavioural events are instantaneous (Altmann 1974), sequences of events comprise repeated similar or differing events in a random or specific order, whereas behavioural

${ }^{*}$ Corresponding author: kirby.smith1@live.vu.edu.au states exist for extended periods of time (Altmann 1974, Mann 1999). Preliminary observations are important to discriminate between behavioural events or states so the most appropriate, efficacious sampling methods can be identified. A comprehensive ethogram can be developed for a species by studying behavioural events and states across differing lifehistory stages and spatial and temporal scales, and may also identify factors influencing behaviour.

() The authors 2015. Open Access under Creative Commons by Attribution Licence. Use, distribution and reproduction are unrestricted. Authors and original publication must be credited. 
Ethograms produced in natural conditions provide baseline data that have been used to identify essential habitat (e.g. Lusseau \& Higham 2004) and assess human impacts on animal behaviour (e.g. Lundquist et al. 2013). This information has subsequently revealed the need for management intervention (e.g. Pierce et al. 2010) and been used to formulate and/or improve management strategies to mitigate disturbances (e.g. Bruce et al. 2005, Dans et al. 2012). Behavioural studies have largely focused on terrestrial vertebrates, particularly birds and mammals (Bonnet et al. 2002, Jennions \& Møller 2003, Ord et al. 2005), and have extended to the marine environment with cetacean research dominant (e.g. Mann 1999). Studies of reptiles and fish are less prevalent (Bonnet et al. 2002, Jennions \& Møller 2003), but advances in electronic tags and photography have facilitated increased research.

The behaviours of sharks are among the least understood as they are a diverse taxon with almost 500 extant species (Compagno 2001) and occupy numerous habitats (Bres 1993). Large-scale migratory behaviours have been documented through cooperative tagging programs (Kohler et al. 1998), satellite (e.g. Brunnschweiler et al. 2010, Stevens et al. 2010) and acoustic tagging (e.g. Werry et al. 2014). Conversely, aggregated sharks have facilitated behavioural observations of reproduction (e.g. Pratt \& Carrier 2001, Whitney et al. 2004) and social interactions (e.g. Klimley \& Nelson 1984, Guttridge et al. 2009), foraging/ feeding (e.g. Heyman et al. 2001, Heithaus et al. 2002), habitat selection and usage (e.g. Gruber et al. 1988, Werry et al. 2012), agonistic interactions (e.g. Johnson \& Nelson 1973, Martin 2007), interactions with tourist snorkelers or scuba divers (e.g. Quiros 2007, Cubero-Pardo et al. 2011) and abnormal/stereotypic displays associated with provisioning tourism (e.g. Laroche et al. 2007, Miller et al. 2011, Brunnschweiler \& Barnett 2013) for various species.

Grey nurse (sandtiger, ragged-tooth) sharks Carcharias taurus (Rafinesque, 1810) have a disjunct distribution in warm-temperate and tropical regions (Compagno 2001), primarily feed on fish (Bass et al. 1975), are slow to reach reproductive maturity (Goldman et al. 2006, Otway \& Ellis 2011) and have a maximum of 2 pups born biennially (Gilmore et al. 1983). Fishing has resulted in worldwide population declines requiring decades for recovery (Mollet \& Cailliet 2002, Otway et al. 2004), and, globally, grey nurse sharks are listed as 'Vulnerable' by the International Union for the Conservation of Nature (IUCN) (Cavanagh et al. 2003). In Australian waters, 2 genetically distinct grey nurse shark populations exist on the east and west coasts (Stow et al. 2006, Ahonen et al. 2009). Historically, the east coast population has been subjected to numerous anthropogenic impacts (Otway et al. 2004, Otway \& Ellis 2011), is estimated to comprise 1146 to 1662 individuals (Lincoln Smith \& Roberts 2010) and is listed as 'Critically Endangered' by the IUCN (Cavanagh et al. 2003) and under Commonwealth and state legislation. Off eastern Australia, adult grey nurse sharks undergo annual (male) and biennial (female) migrations between New South Wales (NSW) and Queensland (QLD) waters $(\sim 4500 \mathrm{~km})$ linked to their reproductive cycles (Bansemer \& Bennett 2009, Otway \& Ellis 2011). Juvenile sharks migrate over smaller spatial scales ( 100 to $400 \mathrm{~km})$ within NSW waters according to seasonal sea-surface temperatures (Otway et al. 2009, Otway \& Ellis 2011). The migratory movements are punctuated by the occupation of aggregation sites for varying periods of time (Otway et al. 2009, Otway \& Ellis 2011). Many of these sites also support a marine wildlife tourism industry focused on passive scuba diver-shark interactions (Smith et al. 2010, 2014, Barker et al. 2011). This sector has previously been identified as a potential threat to the species' recovery (EA 2002), and, consequently, a voluntary code of conduct and regulations for scuba diving were implemented to mitigate possible adverse impacts on the sharks (EA 2002, Talbot et al. 2004, Smith et al. 2014).

The propensity of grey nurse sharks to aggregate also makes them particularly well-suited to ethological study, yet little is known about their behaviours at these sites. Consequently, the aim of this study was to develop a partial ethogram for east Australian grey nurse sharks by studying their swimming (states) and non-swimming (events) behaviours during daylight hours across differing life-history stages and aggregation sites in the absence of scuba diving tourism and commercial and recreational fishers. Importantly, this sampling strategy enables greater generalisation of observed behaviours to the entire population and an improvement on previous studies focusing on a few life-history stages and/or sites. Behavioural information obtained in the absence of scuba diving tourism is also fundamental to assessing the impacts of this marine wildlife tourism sector and directing its future management. The ethogram developed will provide a baseline for behavioural comparison that will enhance existing and future assessments of the sustainability and management of this tourism industry (i.e. Hayward 2003, Otway et al. 2009, Smith et al. 2010, 2014) by enabling modifications to natural behaviour to be identified. 


\section{MATERIALS AND METHODS}

\section{Study sites and sampling}

Observations of swimming and non-swimming behaviours were obtained by a maximum of 3 scuba divers using underwater stereo-video photogrammetry in the absence of scuba diving tourism (Smith et al. 2014) and commercial/recreational fishing. Sampling was conducted at 8 aggregation sites spanning $\sim 800 \mathrm{~km}$ of the Australian east coast (Fig. 1) from March to May in the austral autumn of 2010 to target 5 grey nurse shark life-history stages (Table 1) comprising juvenile males, juvenile females, adult males, gestating females and resting females known to occupy the sites at various times of the year (Bansemer \& Bennett 2009, Otway \& Ellis 2011). Habitats at these sites (Table 1) vary spatially, exhibit general similarities (e.g. gutters, overhangs) but differ in physical and biological variables (e.g. the kelp Ecklonia radiata; Underwood et al. 1991), with sea-surface temperatures ranging from 19 to $28^{\circ} \mathrm{C}$ annually as a result of interacting processes (Otway \& Ellis 2011). Frequent adverse weather events occur throughout the year, limiting site access and scuba diving.

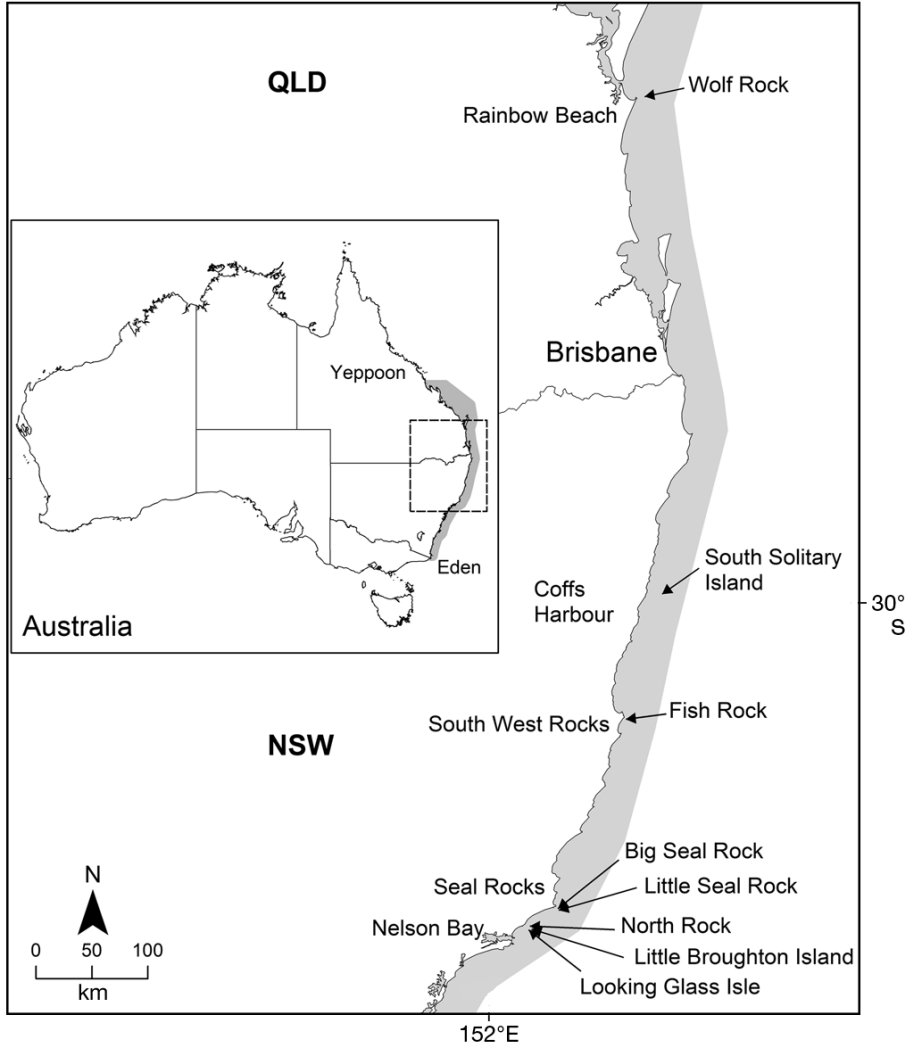

Fig. 1. Geographic range (grey shading) of the grey nurse shark Carcharias taurus and the location of the sites sampled from March to May 2010 to document the swimming and nonswimming behaviours of sharks along the east coast of Australia

Table 1. Summary of the coastal towns, aggregation sites (physical and biological attributes) and sampling periods in 2010 used to document the swimming and non-swimming behaviours of the grey nurse shark Carcharias taurus at different lifehistory stages (LHS) — juvenile males: JM; juvenile females: JF; adult males: AM; gestating females: GF; resting females: RF

\begin{tabular}{|c|c|c|c|c|c|c|}
\hline \multirow{2}{*}{ Coastal town } & \multirow{2}{*}{$\begin{array}{l}\text { Aggregation } \\
\text { site }\end{array}$} & \multirow{2}{*}{$\begin{array}{l}\text { Sampling } \\
\text { period }\end{array}$} & \multirow{2}{*}{$\begin{array}{c}\text { LHS } \\
\text { present }\end{array}$} & \multicolumn{3}{|c|}{ Physical and biological attributes of aggregation site } \\
\hline & & & & $\begin{array}{l}\text { Depth } \\
\text { (m) }\end{array}$ & Topography & $\begin{array}{l}\text { Presence of kelp } \\
\text { Ecklonia radiata }\end{array}$ \\
\hline Rainbow Beach & Wolf Rock & May & GF & $25-35$ & Sand-filled gutters & None \\
\hline Coffs Harbour & $\begin{array}{l}\text { South Solitary } \\
\text { Island }\end{array}$ & May & JM, JF, AM & $10-35$ & $\begin{array}{l}\text { Rock arch, sand-filled } \\
\text { gutters and overhangs }\end{array}$ & None \\
\hline $\begin{array}{l}\text { South West } \\
\text { Rocks }\end{array}$ & Fish Rock & May & $\begin{array}{c}\text { JM, JF, AM, } \\
\text { RF }\end{array}$ & $10-35$ & $\begin{array}{l}\text { Cave and sand/shell } \\
\text { grit-filled gutters }\end{array}$ & None \\
\hline Seal Rocks & Big Seal Rock & Apr & $\mathrm{JM}, \mathrm{JF}, \mathrm{RF}$ & $10-35$ & $\begin{array}{l}\text { Caves and sand-filled } \\
\text { gutters with boulders }\end{array}$ & None \\
\hline Seal Rocks & Little Seal Rock & Apr & $\mathrm{JM}, \mathrm{JF}, \mathrm{RF}$ & $20-40$ & $\begin{array}{l}\text { Caves and sand-filled } \\
\text { gutters with boulders }\end{array}$ & None \\
\hline Nelson Bay & North Rock & Mar & $\mathrm{JM}, \mathrm{JF}, \mathrm{RF}$ & $15-20$ & $\begin{array}{l}\text { Sand-filled gutter with } \\
\text { boulders }\end{array}$ & $\begin{array}{l}\text { On gutter wall in } \\
\text { shallow water }(5 \mathrm{~m})\end{array}$ \\
\hline Nelson Bay & $\begin{array}{l}\text { Little Broughton } \\
\text { Island }\end{array}$ & Mar & $\mathrm{JM}, \mathrm{JF}, \mathrm{RF}$ & $5-10$ & $\begin{array}{l}\text { Topographically complex } \\
\text { with cave, boulders and small } \\
\text { crevices. Surge from breaking } \\
\text { waves reaches the seabed }\end{array}$ & $\begin{array}{l}\text { Widely distri- } \\
\text { buted across } \\
\text { entire habitat }\end{array}$ \\
\hline Nelson Bay & Looking Glass Isle & Mar & $\mathrm{JM}, \mathrm{JF}, \mathrm{RF}$ & $15-35$ & Sand/boulder-filled gutter & None \\
\hline
\end{tabular}




\section{Underwater stereo-video photogrammetry system}

A purpose-built, underwater stereo-video photogrammetry system (USVPS) comprising 2 Sony digital video cameras (Model DCR VX2100E) that recorded 24 frames $\mathrm{s}^{-1}$ was operated by a single scuba diver to capture videos of grey nurse sharks (further details: Shortis \& Harvey 1998, Otway et al. 2008). The cameras were attached $77 \mathrm{~cm}$ apart to a precisely machined aluminium base bar and were angled inwardly by $4^{\circ}$ to ensure overlapping left and right images. A synchronisation unit at the distal end of a $125 \mathrm{~cm}$ long aluminium rod was mounted at the middle of and perpendicular to the base bar. Prior to field sampling the USVPS was calibrated using a standardised protocol in a public swimming pool with a $140 \times 140 \times 140 \mathrm{~cm}$ anodised aluminium calibration cube with 80 predetermined, reflective points and subsequent use of specialised software (Cal Version 1.20, OSeaGIS). The USVPS enabled stereo images of sharks with a total length (TL) of $3 \mathrm{~m}$ at a minimum range of $3 \mathrm{~m}$, additional morphometric measurements (Compagno 2001) and the documentation of swimming and non-swimming behaviours.

After field sampling, videos were downloaded and saved in AVI format with Adobe Premiere v. 6.0, and then analysed with EventMeasure (OSeaGIS) which uses a 'point and click' approach with synchronised images from the left and right cameras to measure various lengths. The software computed various lengths and the range to the base bar (in $\mathrm{mm}$ ) with estimates of a known length accurate and precise to \pm 0.2 and $\pm 0.3-1.2 \%$, respectively (Otway et al. 2008).

\section{Grey nurse shark life-history stages}

Grey nurse shark life-history stages present at each site were determined using the general methods of Smith et al. (2014) and USVPS length measurements. Precaudal length (PCL; Fig. 2a) was measured from the tip of the snout to the precaudal pit (Compagno 2001, Last \& Stevens 2009) and selected because of greater accuracy than TL (Francis 2006). Total length

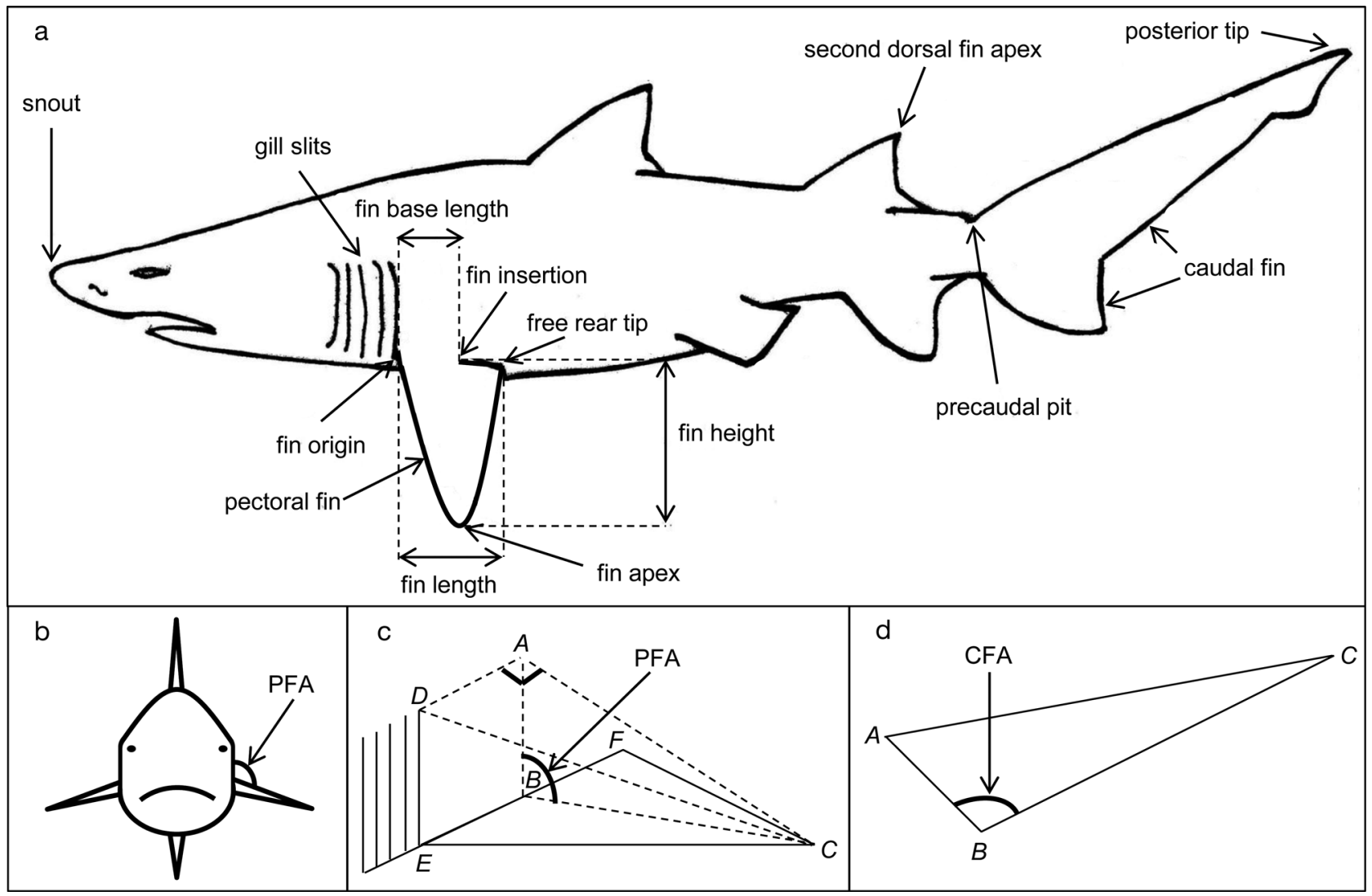

Fig. 2. Illustration showing the $(\mathrm{a}, \mathrm{b})$ morphometric and $(\mathrm{c}, \mathrm{d})$ trigonometric distances measured to calculate the pectoral fin angle (PFA) and caudal fin angle (CFA) of the grey nurse shark Carcharias taurus 
was then calculated (nearest $\mathrm{mm}$ ) using a significant linear regression (i.e. $\mathrm{TL}=1.368 \mathrm{PCL}+0.069$, with TL and PCL in $\mathrm{m}, \mathrm{n}=66, \mathrm{R}^{2}=0.99, \mathrm{p}<0.001$ ) developed via necropsies (Otway et al. 2004, 2008). Sexual maturity was determined from gender (claspers in males), TL and maturity ogives (i.e. $50.0 \%$ sexual maturity: males $=2.10 \mathrm{~m}$ at 6 to $7 \mathrm{yr}$, females $=2.59 \mathrm{~m}$

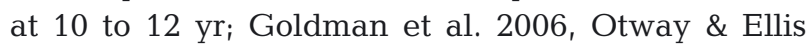
2011). The numbers (percentages) of juvenile male, juvenile female, adult male, gestating female and resting female sharks occupying each site were then quantified.

\section{Grey nurse shark swimming behaviours}

Previously described swimming behaviours of grey nurse sharks (Table 2) were quantified at each site from the stereo-videos using instantaneous scan samples (Altmann 1974) separated by 30 s intervals. Scanning commenced when the entire body of at least 1 shark was present within the field of view for at least $10 \mathrm{~s}$. During the scan, the swimming behaviour of each shark within $10 \mathrm{~m}$ of the USVPS was recorded, and the proportions of sharks exhibiting different swimming behaviours were calculated. Scanning ceased when all sharks left the field of view for $\geq 5$ s (i.e. 120 frames). The number of scans of sharks in each behavioural state (hovering, milling and active swimming) at each site and across all sites were then calculated as percentages of the total number of scans per site and sites combined (Smith et al. 2014).

\section{Tail beats}

Grey nurse shark tail-beat frequency (TBF, in beats $\min ^{-1}$ ) when hovering, milling and actively swimming was documented for each shark sampled for pectoral fin angle (PFA) and caudal fin angle (CFA). Tail beats were defined as the movement of the tail from the midline to the left or right and back to the midline (Hannon \& Crook 2004, Barker et al. 2011) and were counted for each shark whilst in the field of view.

Rates of movement

Estimates of the rate of movement (ROM, in $\mathrm{m} \mathrm{s}^{-1}$ ) were obtained from grey nurse sharks selected using continuous observation (Altmann 1974) at each site.
The ROM was only quantified for milling or active swimming as there is no forward motion when hovering. The PCL, gender and time elapsed from when the shark snout entered the field of view until the anterior edge of the precaudal pit became visible were recorded.

\section{Pectoral fin positions}

Continuous observation (Altmann 1974) was again used to select grey nurse sharks for sampling the left or right PFA, gender and PCL whilst hovering, milling and actively swimming at each site. The PFA (Fig. 2a,b) was defined as the angle subtended by Point $A$ (see below), the pectoral fin insertion (Point $B$ ) and the pectoral fin apex (Point $C$ ). The USVPS was used to measure (nearest $\mathrm{mm}$ ) the length from the top (Point $D$ ) to the bottom (Point $E$ ) of the fifth gill slit (Line $D E$, Fig. 2a,c), pectoral fin length (PFL) from the pectoral fin origin at the bottom of the fifth gill slit (Point $E$ ) to the pectoral fin free rear tip (Point $F$, Line $E F)$, and the length between the pectoral fin apex and the top of the fifth gill slit (Line $C D$ ). Further regression relationships developed from necropsy data were used to assist with some pectoral fin calculations. Pectoral fin height $\left(\mathrm{PFH}\right.$, Line $B C_{\text {; }}$ Fig. 2a,c) was calculated using PFL in a significant linear regression of $\mathrm{PFH}=1.212 \mathrm{PFL}-22.752(\mathrm{n}=53$, $\left.\mathrm{R}^{2}=0.96, \mathrm{p}<0.001\right)$. Pectoral fin base length (PFBL, Line $B E=A D$; Fig. 2a,c) was then calculated using $\mathrm{PFL}$ in a significant linear regression of $\mathrm{PFBL}=$ $0.671 \mathrm{PFL}-25.537\left(\mathrm{n}=53, \mathrm{R}^{2}=0.94, \mathrm{p}<0.001\right)$ as the pectoral fin insertion (Point $B$ ) could not always be observed in the video frames. As Point $A$ could not be accurately identified on the shark, it was located at the top of an imaginary line of equal length to the fifth gill slit (i.e. Line $A B=D E$ ) and positioned perpendicular to the pectoral fin insertion (Point $B$; Fig. 2c). With lengths $A D$ and $C D$ known, the length of Line $A C$ was calculated using the Pythagorean formula. Finally, PFA (Angle $A B C$ ) was calculated using the law of cosines (De Sapio 1976), with $A B C=$ $\operatorname{arcos}\left[\left(B C^{2}+A B^{2}-A C^{2}\right) / 2(B C \times A B)\right]$. The PFA of turning sharks together with the turn duration (s) were quantified where possible.

\section{Caudal fin positions}

The CFA (Fig. 2a,d) was defined as the angle subtended by the second dorsal fin apex (Point $A$ ), the anterior edge of the precaudal pit (Point $B$ ) and the 
Table 2 (continued on next page). Descriptions of the swimming and non-swimming behaviours of the grey nurse shark Carcharias taurus previously observed in the wild and in captivity

\begin{tabular}{|c|c|c|c|}
\hline \multirow{2}{*}{$\begin{array}{l}\text { Behaviour category } \\
\text { and type }\end{array}$} & \multirow[t]{2}{*}{ General description } & \multicolumn{2}{|c|}{ Grey nurse sharks } \\
\hline & & \multicolumn{2}{|c|}{ Location observed References } \\
\hline \multicolumn{4}{|l|}{ Swimming } \\
\hline $\begin{array}{l}\text { Active/accelerated } \\
\text { swimming }\end{array}$ & $\begin{array}{l}\text { Persistent movement in a general direction at a greater } \\
\text { speed than milling }\end{array}$ & Wild & $\begin{array}{l}\text { Hayward }(2003), \\
\text { Smith et al. }(2010,2014)\end{array}$ \\
\hline Cruising & Low level of activity without directional change & Wild & Hayward (2003) \\
\hline Hovering & Sharks appear to be motionless & Wild & $\begin{array}{l}\text { Hayward (2003), } \\
\text { Smith et al. (2014) }\end{array}$ \\
\hline Milling & $\begin{array}{l}\text { Low level of activity with frequent directional changes } \\
\text { within the same area }\end{array}$ & Wild & Smith et al. $(2010,2014)$ \\
\hline \multicolumn{4}{|l|}{$\begin{array}{l}\text { Non-swimming } \\
\text { Feeding }\end{array}$} \\
\hline Solitary & Solitary individuals take prey & Captivity & Gilmore et al. (1983) \\
\hline Cooperative & $\begin{array}{l}\text { Shark school surrounds and concentrates schooling prey, } \\
\text { sometimes with tail slapping to stun prey and subsequent } \\
\text { tail popping }\end{array}$ & Wild & $\begin{array}{l}\text { Compagno (2001), } \\
\text { Martin (2007) }\end{array}$ \\
\hline \multicolumn{4}{|l|}{ Reproductive } \\
\hline \multirow[t]{2}{*}{ Clasper flexion } & Movement of a clasper forward and outward & Wild & $\begin{array}{l}\text { Myrberg \& Gruber } \\
(1974)^{\mathrm{a}} \text {, Smith et al. } \\
(2010)\end{array}$ \\
\hline & & Captivity & Gordon (1993) \\
\hline Cupping & $\begin{array}{l}\text { Female forms a cup-like shape with pelvic fins immediately } \\
\text { prior to flaring }\end{array}$ & Captivity & Gordon (1993) \\
\hline Flaring & Outward flaring of pelvic fins to expose the cloaca & Captivity & Gordon (1993) \\
\hline $\begin{array}{l}\text { Following/ } \\
\text { tailing }\end{array}$ & $\begin{array}{l}\text { Shark closely follows conspecific, restricting the movement } \\
\text { of its caudal fin }\end{array}$ & Captivity & $\begin{array}{l}\text { Myrberg \& Gruber } \\
(1974)^{\mathrm{a}}, \text { Gordon }(1993)\end{array}$ \\
\hline Nosing & $\begin{array}{l}\text { Male approaches female from behind and underneath to } \\
\text { place his snout beneath her cloaca }\end{array}$ & Captivity & Gordon (1993) \\
\hline Shielding & $\begin{array}{l}\text { Female shark swims close to the substrate to avoid male } \\
\text { shark approaches to her cloaca }\end{array}$ & Captivity & Gordon (1993) \\
\hline Snapping & Male inflicting a swift bite to a perceived threat & Captivity & Gordon (1993) \\
\hline Splaying & $\begin{array}{l}\text { Extension of both claspers upward and/or outward or } \\
\text { crossing of claspers }\end{array}$ & Captivity & Gordon (1993) \\
\hline Stalking & Circling and closely swimming past other species & Captivity & Gordon (1993) \\
\hline Stalling & Ceasing forward motion to hover above the substrate & Captivity & Gordon (1993) \\
\hline $\begin{array}{l}\text { Submissive } \\
\text { behaviour }\end{array}$ & $\begin{array}{l}\text { Female swims very slowly with her head lowered } \\
\left(\sim 15^{\circ} \text { below the longitudinal axis) to expose her pelvic region }\right.\end{array}$ & Captivity & Gordon (1993) \\
\hline Mating bites & $\begin{array}{l}\text { Male bites the pectoral fins of a female to hold her in position } \\
\text { for mating, causing scarring around her pectoral fins } \\
\text { and head }\end{array}$ & Wild & $\begin{array}{l}\text { Bass et al. (1975), } \\
\text { Gilmore et al. (1983), } \\
\text { Bansemer \& Bennett } \\
(2009)\end{array}$ \\
\hline & & Captivity & Gordon (1993) \\
\hline Parturition & $\begin{array}{l}\text { Gestating female shark gives birth to a maximum of } 2 \text { pups } \\
\text { born headfirst }\end{array}$ & Captivity & $\begin{array}{l}\text { Gilmore et al. (1983), } \\
\text { Henningsen et al. (2004) }\end{array}$ \\
\hline \multicolumn{4}{|l|}{ Respiratory } \\
\hline \multirow[t]{2}{*}{$\begin{array}{l}\text { Active ventilation/ } \\
\text { buccal pumping }\end{array}$} & $\begin{array}{l}\text { Opening and closing of the mouth to facilitate water } \\
\text { movement over the gills }\end{array}$ & Wild & $\begin{array}{l}\text { Smith et al. (2010), } \\
\text { Barker et al. (2011) }\end{array}$ \\
\hline & & Captivity & $\begin{array}{l}\text { Hannon \& Crook } \\
(2004)\end{array}$ \\
\hline \multirow[t]{2}{*}{$\begin{array}{l}\text { Passive/ram } \\
\text { ventilation }\end{array}$} & $\begin{array}{l}\text { Slight opening of the mouth to enable water to pass over the } \\
\text { gills, typically adopted during milling and active swimming }\end{array}$ & Wild & Barker et al. (2011) \\
\hline & & Captivity & $\begin{array}{l}\text { Hannon \& } \\
\text { Crook }(2004)\end{array}$ \\
\hline \multicolumn{4}{|l|}{ Grooming } \\
\hline Chafing & $\begin{array}{l}\text { Rolling of the body along the substrate to remove possible } \\
\text { parasites }\end{array}$ & Wild & $\begin{array}{l}\text { Myrberg \& Gruber } \\
(1974)^{\mathrm{a}}, \text { Hayward (2003) }\end{array}$ \\
\hline Gill puff & $\begin{array}{l}\text { Sustained or momentary expansion of the gills to remove } \\
\text { object(s) and/or readjust muscular control }\end{array}$ & Wild & $\begin{array}{l}\text { Myrberg \& Gruber } \\
(1974)^{\mathrm{a}} \text {, Smith et al. } \\
(2010)\end{array}$ \\
\hline
\end{tabular}


Table 2 (continued)

\begin{tabular}{|c|c|c|c|}
\hline \multirow{2}{*}{$\begin{array}{l}\text { Behaviour category } \\
\text { and type }\end{array}$} & \multirow[t]{2}{*}{ General description } & \multicolumn{2}{|c|}{ Grey nurse sharks } \\
\hline & & Location observed & References \\
\hline \multicolumn{4}{|l|}{ Agonistic } \\
\hline Charging & $\begin{array}{l}\text { Fast approach towards a perceived threat, usually } \\
\text { concluded by a quick turn away when close }\end{array}$ & Wild & Martin (2007) \\
\hline Flank displaying & $\begin{array}{l}\text { Sustained (i.e. }>5 \mathrm{~s} \text { ) exposure of the underside toward } \\
\text { a perceived threat }\end{array}$ & Wild & Martin (2007) \\
\hline Give-way & $\begin{array}{l}\text { Shark changes course of direction to avoid an } \\
\text { approaching conspecific }\end{array}$ & Captivity & $\begin{array}{l}\text { Myrberg \& Gruber } \\
(1974)^{\mathrm{a}}, \text { Hannon \& } \\
\text { Crook (2004) }\end{array}$ \\
\hline Jaw gaping & $\begin{array}{l}\text { Slow, sustained opening of the mouth and wider than } \\
\text { during ram ventilation }\end{array}$ & Wild & $\begin{array}{l}\text { Martin (2007), } \\
\text { Smith et al. (2010) }\end{array}$ \\
\hline $\begin{array}{l}\text { Open jawed } \\
\text { tooth raking }\end{array}$ & $\begin{array}{l}\text { Upper dentition of shark makes forceful and injurious } \\
\text { contact with a perceived threat }\end{array}$ & Wild & Martin (2007) \\
\hline $\begin{array}{l}\text { Pectoral fin } \\
\text { depression }\end{array}$ & $\begin{array}{l}\text { Sustained (i.e. }>5 \mathrm{~s} \text { ) and severe depression of both } \\
\text { pectoral fins }\end{array}$ & Wild & $\begin{array}{l}\text { Johnson \& Nelson } \\
(1973)^{\mathrm{a}}, \text { Martin (2007), } \\
\text { Barker et al. (2011) }\end{array}$ \\
\hline Rapid withdrawal & Fast movement away from a perceived threat & Wild & $\begin{array}{l}\text { Martin (2007), } \\
\text { Smith et al. (2010) }\end{array}$ \\
\hline $\begin{array}{l}\text { Reduced swim- } \\
\text { ming efficiency }\end{array}$ & $\begin{array}{l}\text { Shark appears almost stationary despite exaggerated } \\
\text { swimming movements }\end{array}$ & Wild & Martin (2007) \\
\hline $\begin{array}{l}\text { Stiff or jerky } \\
\text { movement }\end{array}$ & Awkward body movements during swimming & Wild & $\begin{array}{l}\text { Martin (2007), } \\
\text { Smith et al. (2010) }\end{array}$ \\
\hline $\begin{array}{l}\text { Tail cracking/ } \\
\text { popping }\end{array}$ & $\begin{array}{l}\text { Loud, abrupt sound sometimes generated by the very fast } \\
\text { movement of the caudal fin during rapid withdrawal }\end{array}$ & Wild & $\begin{array}{l}\text { Hayward (2003), Martin } \\
(2007), \text { Smith et al. (2010), } \\
\text { Barker et al. (2011) }\end{array}$ \\
\hline Tail slapping & $\begin{array}{l}\text { Swift movement of the caudal fin at the surface, hitting or } \\
\text { splashing a perceived threat }\end{array}$ & Wild & Martin (2007) \\
\hline
\end{tabular}

caudal fin posterior tip (Point $C$ ) and was measured after the PFA was quantified. Lengths $A B, B C$ and $A C$ were measured (nearest $\mathrm{mm}$ ) with the USVPS, and CFA was calculated using the law of cosines.

\section{Grey nurse shark non-swimming behaviours}

Non-swimming behaviours of grey nurse sharks (Table 2) were quantified from the stereo-videos obtained at each site using continuous observation (Altmann 1974) of all sharks simultaneously and the general methods of Smith et al. (2010). Active respiration rates (i.e. buccal pumping) were quantified as the number of buccal pumps per minute for hovering and milling sharks. For other non-swimming behaviours the focal shark's gender, PCL and distance to the nearest conspecific (to the nearest $\mathrm{mm}$ ), behaviour duration (to the nearest $0.01 \mathrm{~s}$ ), number of conspecifics $\leq 10 \mathrm{~m}$ from the USVPS and likely behavioural trigger(s) were documented. Where possible, PFA and CFA were measured and additional morphometric measurements were obtained for some be- haviours. Behavioural events repeated by the same shark within $20 \mathrm{~s}$ of the initial occurrence were considered components of a sequence (Altmann 1974).

\section{Statistical analyses}

Statistical analyses were done with an initial Type I $(\alpha)$ error rate of $p=0.05$. Data for TBF, PFA and CFA were repartitioned into swimming behaviours, life-history stages, sites and gender so each dataset generated 4 separate analyses. Consequently, the family-wise error rate was calculated using the Šidák-Bonferroni adjustment (Šidák 1967), which resulted in a significance level of $p<0.05$ in these analyses. Grey nurse shark life-history stages were summarised for each site and compared using a contingency table analysis. Sampling effort and swimming behaviour (including TBF and ROM, where possible) were examined using balanced 1or 2-factor analyses of variance (ANOVA) with arcsine transformation of proportional data and Cochran's test for homogeneity of variances (Underwood 
1997). When variances were heterogeneous a power transformation was used for ordinal data. The existence of serial correlation was examined via plots of residuals against time and tested with the DurbinWatson statistic (Durbin \& Watson 1950, 1951, Farebrother 1980). To enhance data independence, approximately $30.0 \%$ of the scans recorded per site were randomly selected and used for analyses (Smith et al. 2014). Where possible, post hoc pooling of the interaction term and, subsequently, either main effect in the fully orthogonal, 2-factor ANOVA was done when the terms were not significant at $\mathrm{p} \geq$ 0.25 (Underwood 1997) to increase the power of the test. After ANOVA, significant differences among means were identified using Student-NewmanKeuls (SNK) tests (Underwood 1997). The TBF and ROM were plotted against TL for swimming behaviours and examined for significant linear relationships. The PFA and CFA were also plotted against TL and TBF for all swimming behaviours to test for associations.

Analyses of PFA and CFA among swimming behaviours, life-history stages, sites and gender were done using various tests associated with the Von Mises (circular normal) distribution (Batschelet 1981). Rayleigh tests determined whether there were significant mean directions among PFA and CFA according to swimming behaviours, life-history stages, sites and gender (Batschelet 1981). Angular variances were calculated, and significant differences among mean angles were examined using Watson-Williams 2- and multi-sample F-tests (Batschelet 1981).

\section{RESULTS}

\section{Sampling effort}

Stereo-videos were obtained during 29 research dives across the 8 sites in east Australia and yielded 35, 46, 41, 53, 43, 47, 46 and 16 scans at Wolf Rock, South Solitary Island, Fish Rock, Big Seal Rock, Little Seal Rock, North Rock, Little Broughton Island and Looking Glass Isle, respectively. The mean duration of synchronised video per dive (range $=8.27-$ $11.09 \mathrm{~min}$ ) did not differ significantly among sites (ANOVA: $F_{7,8}=1.18, \mathrm{p}=0.41$ ). Similarly, the duration of observations assessing shark life-history stages and swimming and non-swimming behaviours did not differ significantly among sites (ANOVA: $F_{7,8}=$ 2.65, $\mathrm{p}=0.10$ ), indicating consistent sampling effort across all sites. Numbers of grey nurse sharks varied markedly across sites (range $=9-79$ sharks) and totalled 273 individuals from 5 life-history stages comprising 14 juvenile males, 138 juvenile females, 53 adult males, 18 gestating females, 8 resting females and a further 42 sharks of undetermined gender.

\section{Grey nurse shark life-history stages}

Numbers of grey nurse sharks in the 5 life-history stages varied, and proportions of juveniles and adults differed significantly among sites (chi-squared test: $\left.\chi^{2}{ }_{7}=107.92, \mathrm{p}<0.001\right)$. The Wolf Rock population $(\mathrm{n}=18)$ comprised gestating females $(100.0 \%)$, whereas, at South Solitary Island, sharks (n = 22) were mainly adult males (72.7\%) and some juveniles $(27.3 \%)$. At Fish Rock, the population ( $\mathrm{n}=15)$ comprised juveniles and adults of both genders, with adult males $(40.0 \%)$ and juvenile females (33.3\%) being predominant. Similarly, at Big Seal Rock, sharks ( $\mathrm{n}=79$ ) comprised mainly juvenile females $(46.8 \%)$ and adult males $(34.2 \%)$. Sharks at Little Seal Rock $(n=33)$ were primarily juvenile females $(81.8 \%)$, but there were some adults $(12.1 \%)$. The North Rock population ( $\mathrm{n}=67$ ) comprised juveniles and adults, but was dominated by juvenile females $(89.6 \%)$. Lastly, sharks at Little Broughton Island ( $\mathrm{n}=$ 30) and Looking Glass Isle $(n=9)$ were all juveniles and included at least 4 pups.

\section{Grey nurse shark swimming behaviours}

Hovering, milling and active swimming were the main swimming behaviours exhibited by grey nurse sharks in this study (Fig. 3). Hovering sharks faced into a current and did not gain net forward motion as their tail beats maintained a stationary position in the water column (Table 3). Milling comprised slow movements and incorporated frequent directional changes either confined to a particular area within a gutter or encompassed the entire gutter with turns at either end (Table 3). Turning was achieved by momentary depression of a pectoral fin to initiate a horizontal turn in the direction of the depressed fin. The mean $( \pm \mathrm{SD}$, range) duration of measured turns was $5.61 \mathrm{~s}( \pm 3.46,2.04-10.20 \mathrm{~s})$, with the relevant measurable pectoral fin depressed to $134^{\circ}$ and a mean (angular variance, range) $\mathrm{CFA}$ of $78^{\circ}\left(6,59-97^{\circ}\right)$. Actively swimming sharks were generally solitary individuals that showed unidirectional movements at greater speeds than milling and covered the spatial extent of an entire gutter (Table 3). 


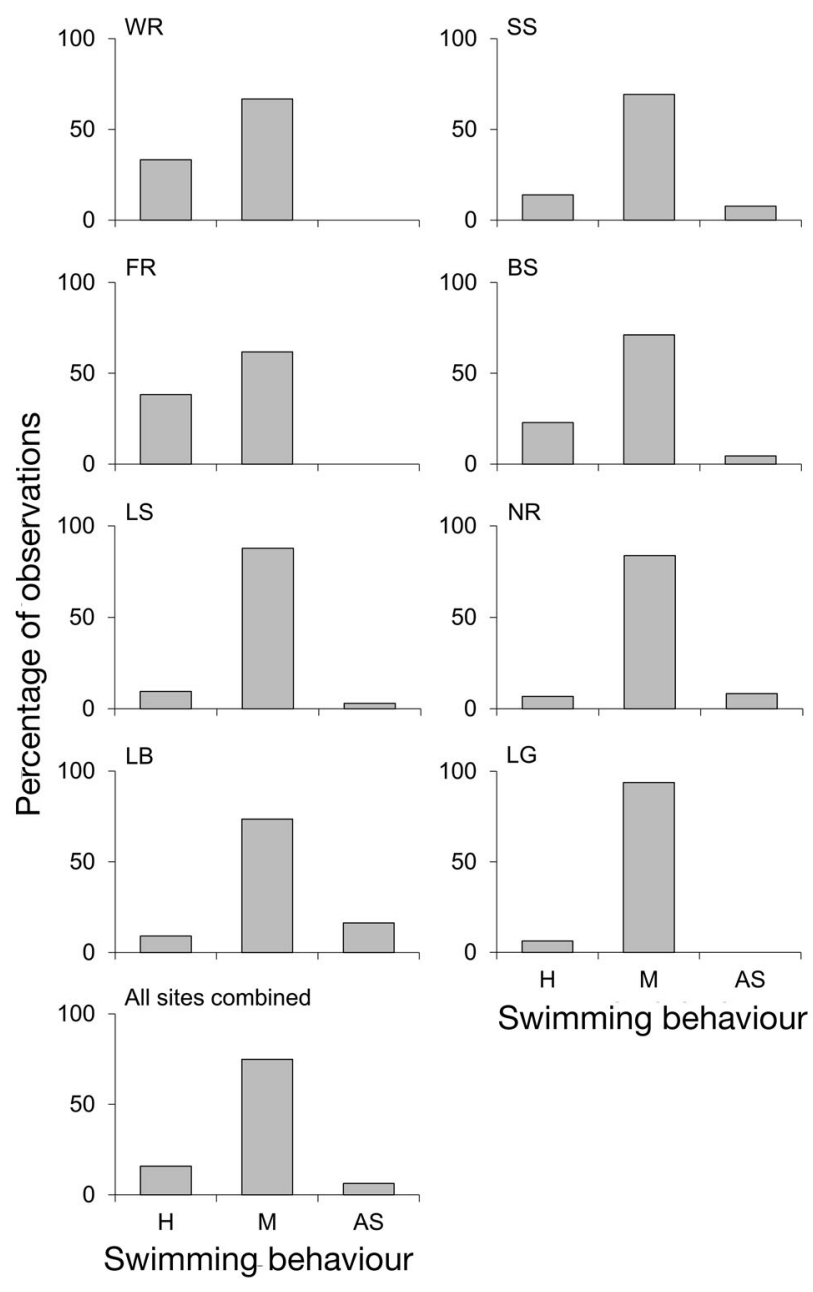

Fig. 3. Observations of the swimming behaviour of the grey nurse shark Carcharias taurus, with the frequency of occurrence of hovering $(\mathrm{H})$, milling $(\mathrm{M})$ and active swimming (AS) sampled from March to May 2010 at Wolf Rock (WR), South Solitary Island (SS), Fish Rock (FR), Big Seal Rock (BS), Little Seal Rock (LS), North Rock (NR), Little Broughton Island (LB) and Looking Glass Isle (LG), east Australia

Swimming behaviour data were not serially correlated as plots of residuals against time showed random patterns and Durbin-Watson tests were not significant ( $d=1.44-1.83$ across all tests, $\mathrm{p}>0.05)$. The fully orthogonal, 2-factor ANOVA with sites (random) and swimming behaviour (fixed) showed that the sites $\times$ swimming behaviour interaction and sites main effect were non-significant $(\mathrm{p}=0.55$ and $\mathrm{p}>$ 0.99, respectively). Post hoc pooling of these terms showed milling $(74.9 \%)$ was exhibited significantly more than hovering (15.9\%) which was, in turn, significantly greater than active swimming (6.2\%) (ANOVA: $F_{2,117}=46.64, \mathrm{p}<0.0005$ and SNK test: $\mathrm{p}<$ 0.05). Mean TBF differed significantly among swimming behaviours and sites (ANOVA: $F_{2,96}=76.31$, p <
0.0005 and $F_{7,56}=2.22, \mathrm{p}<0.05$, respectively) but not life-history stages or gender (ANOVA: $F_{4,25}=1.22$, $\mathrm{p}=0.33$ and $F_{1,162}=0.15, \mathrm{p}=0.70$, respectively). Mean TBF was significantly greater during active swimming compared with milling and hovering which did not differ (Table 3; SNK test: $\mathrm{p}<0.05$ ). Although the SNK test was inconclusive, the mean TBF was substantially greater at Little Broughton Island than at other sites (Table 3). Quantifying the ROM proved more difficult and constrained the number of replicates obtained; hence, data were not analysed statistically and merely tabulated (Table 3). Nevertheless, there was a trend towards a greater mean ROM for active swimming compared with milling (Table 3). The TBF significantly decreased as TL increased for milling and active swimming, but these linear regressions only accounted for 11.6 and $34.8 \%$ of the respective variances (Table 4). Conversely, there was no significant linear regression relationship with TBF on TL when sharks were hovering or between ROM and TL when milling and active swimming were combined.

Mean PFA did not differ significantly among swimming behaviours, life-history stages, or gender (Watson-Williams tests: $F_{2,205}=0.33, \mathrm{p}>0.25 ; F_{4,203}=$ $-0.54, \mathrm{p}>0.25 ; F_{1,206}=-0.25, \mathrm{p}>0.25$, respectively), but exhibited significant differences among sites $\left(F_{7,200}=4.83, \mathrm{p}<0.0005\right)$. Mean PFA was greatest at Little Broughton Island, least at Wolf Rock and North Rock, and similar at the remaining sites (Table 5).

Mean CFA differed significantly among swimming behaviours (Watson-Williams tests: $F_{2,215}=12.39$, p < 0.0005), but not life-history stages, sites, or gender (Watson-Williams tests: $F_{4,213}=1.28, \mathrm{p}>0.10 ; F_{7,210}=$ 1.36, p $>0.25 ; F_{1,216}=-66.53, \mathrm{p}>0.25$, respectively). Mean CFA was least when sharks were actively swimming or milling and greatest when hovering (Table 5). The PFA and CFA were not correlated with TL or TBF during hovering, milling, or active swimming.

\section{Grey nurse shark non-swimming behaviours}

Feeding and reproductive behaviours were not observed at any site. Most grey nurse sharks exhibited passive (ram) ventilation across all sites, but active respiration (buccal pumping) rates were documented for 5 sharks (2.10-2.60 m TL) with a mean $\left( \pm \mathrm{SD}\right.$, range) rate of 20.4 buccal pumps $\min ^{-1}(0.55$, 20-21 buccal pumps min ${ }^{-1}$ ). Chafing, gill puff, head snapping, palatoquadrate protrusion, rapid withdrawal and stand back behaviours were exhibited by 


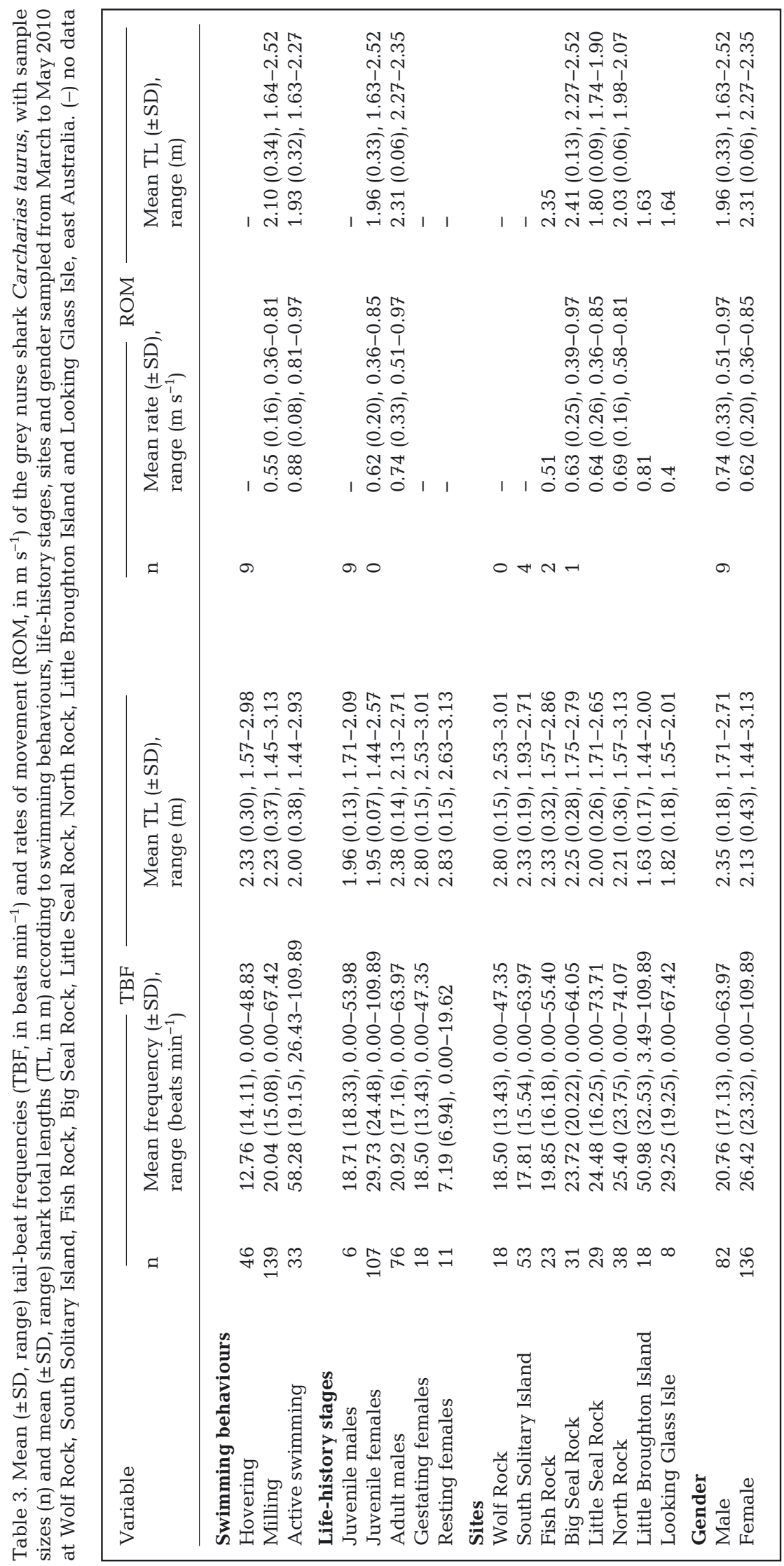

$18(6.6 \%)$ sharks, with 1 shark exhibiting gill puff, head snapping and palatoquadrate protrusion in a sequence. Combined, nonswimming behaviours accounted for $0.8 \%$ of time spent observing sharks pooled across all sites. Descriptions and other details for these non-swimming behaviours are summarised in Table 6. Rapid withdrawal was the most frequent non-swimming behaviour, followed by gill puff, head snapping and equal occurrences of chafing, palatoquadrate protrusion and stand back. Non-swimming behaviours were exhibited by 12 juvenile females $(8.7 \%$ of all juvenile females), 4 adult males $(7.6 \%$ of all adult males), 1 juvenile male $(7.1 \%$ of all juvenile males) and 1 adult shark of unknown gender (Table 6). Ranges in PFA and CFA were similar to those for swimming behaviours (Tables $5 \& 6$ ). The mean $( \pm \mathrm{SD}$, range) distance between a shark exhibiting a non-swimming behaviour and the closest conspecific was $2.12 \mathrm{~m}( \pm 1.61,0.28-$ $4.53 \mathrm{~m})$. The onset of non-swimming behaviours did not appear to be related to the number of conspecifics in close proximity as the mean $( \pm \mathrm{SD}$, range) number of conspecifics $\leq 10 \mathrm{~m}$ from the USVPS present when these behaviours were observed was $1.05 \quad \pm 0.97$, $0-3)$. The shark that exhibited gill puff, head snapping and palatoquadrate protrusion had a mean $( \pm \mathrm{SD}$, range) maximum gape of $300 \mathrm{~mm}( \pm 50,251-350 \mathrm{~mm})$. During stand back 1 juvenile female exhibited a second burst of speed $5.40 \mathrm{~s}$ after the initial retreat at a distance of $5.64 \mathrm{~m}$ from the other juvenile female.

A gill puff event exhibited by an adult male and 6 rapid withdrawal events exhibited by juvenile females were likely attributable to research diver presence (Table 6) and only accounted for about $0.1 \%$ 


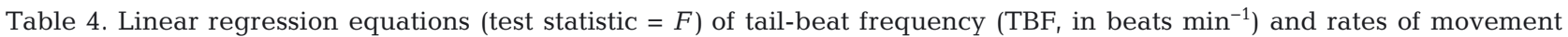
$\left(\mathrm{ROM}\right.$, in $\mathrm{m} \mathrm{s}^{-1}$ ) on total length ( $\mathrm{TL}$, in $\left.\mathrm{m}\right)$ for the grey nurse shark Carcharias taurus when hovering, milling and active swimming, with sample sizes (n) and goodness-of-fit $\left(\mathrm{R}^{2}\right)$ sampled from March to May 2010 at Wolf Rock, South Solitary Island, Fish Rock, Big Seal Rock, Little Seal Rock, North Rock, Little Broughton Island and Looking Glass Isle, east Australia

\begin{tabular}{|lllrrrr|}
\hline Relationship & Swimming behaviour & Equation & $\mathrm{n}$ & $\mathrm{R}^{2}$ & $F$ & $\mathrm{p}$ \\
\hline TBF on TL & Hovering & $y=-0.6987 x+14.388$ & 46 & 0.0002 & 0.01 & 0.92 \\
& Milling & $y=-13.857 x+50.903$ & 139 & 0.1164 & 18.05 & 0.0004 \\
& Active swimming & $y=-29.857 x+117.96$ & 33 & 0.3479 & 16.54 & 0.0003 \\
ROM on TL & Milling and active & $y=-0.06 x+0.7536$ & 12 & 0.0093 & 0.09 & 0.77 \\
& swimming combined & & & & & \\
\hline
\end{tabular}

of observation time pooled across all sites. The gill puff occurred at South Solitary Island in association with 3 camera flashes. After the third flash, the shark altered its swimming behaviour from milling to active swimming, but resumed milling after $10.28 \mathrm{~s}$ and did not leave the area. Rapid withdrawals occurred when a shark swam to within $3 \mathrm{~m}$ of the USVPS base bar once at Big Seal Rock and Little Seal Rock and twice at Little Broughton Island. Rapid withdrawal was also observed at Little Broughton Island after 1 diver approached to within $1 \mathrm{~m}$ of a shark. In contrast, exhaled air bubbles from a diver made contact with a shark and elicited a rapid withdrawal event at Little Seal Rock. The final rapid withdrawal occurred when surge moved a shark close to a rock wall of the North Rock shark gutter.

\section{DISCUSSION}

Significant sexual and size segregation of grey nurse sharks was evident among aggregation sites off eastern Australia, which is consistent with previous research (Bansemer \& Bennett 2009, Otway et al. 2009, Otway \& Ellis 2011). There were also overlaps which enabled behavioural analysis of different life-history stages at each site and the development of a partial ethogram. While it is not possible to completely eliminate the potential effects of observers when developing an ethogram for sharks due to their sensory capabilities (Bres 1993), in this study, the presence of research divers did not overtly alter grey nurse shark behaviour, as possible responses accounted for $<0.1 \%$ of observation time. This is consistent with observations from a recent study documenting interactions between grey nurse sharks and tourist scuba divers at 4 sites (Smith et al. 2014). Nevertheless, the possibility of observer influence on shark behaviour cannot be completely discounted.

\section{Grey nurse shark swimming behaviours}

Sharks exhibited hovering, milling and active swimming at most sites, a finding similar to those of other behavioural (Hayward 2003, Smith et al. 2010, 2014) and localised movement (Bansemer \& Bennett 2009, Otway et al. 2009) studies. Hovering and milling accounted for $>90.0 \%$ of swimming behaviour observations, with significantly more milling, which accords with other studies (Hayward 2003, Smith et al. 2010, 2014). Swimming speed (i.e. ROM) provides an important measurement of energy expenditure in sharks, with rates of $<2 \mathrm{~m} \mathrm{~s}^{-1}$ for all continuously swimming wild sharks assessed (Bone 1989, Shadwick \& Goldbogen 2012). Grey nurse shark swimming speeds did not exceed this ROM and were least when milling and greatest during active swimming, suggesting low levels of activity and energy expenditure when aggregated during daylight hours.

Hovering sharks used slow tail beats to maintain station, with the caudal fin placed significantly lower in the water column and likely minimising forward propulsion. Laboratory studies of swimming biomechanics in the North American leopard shark Triakis semifasciata showed that pectoral fins were held at negative dihedral angles (i.e. below horizontal) of approximately 5,23 and $35^{\circ}$ when descending, holding and ascending, respectively (Wilga \& Lauder 2000, Maia et al. 2012). Assuming these observations apply to grey nurse sharks, the PFA documented in this study enables comparisons. Whilst hovering, the mean dihedral angle of grey nurse sharks was consistent with North American leopard sharks. Milling sharks also swam with slow tail beats, but held their caudal fins higher and had a greater range in CFAs. The mean dihedral angle was similar to that noted during hovering, but had a larger range with the fins used for manoeuvring. In contrast, actively swim- 


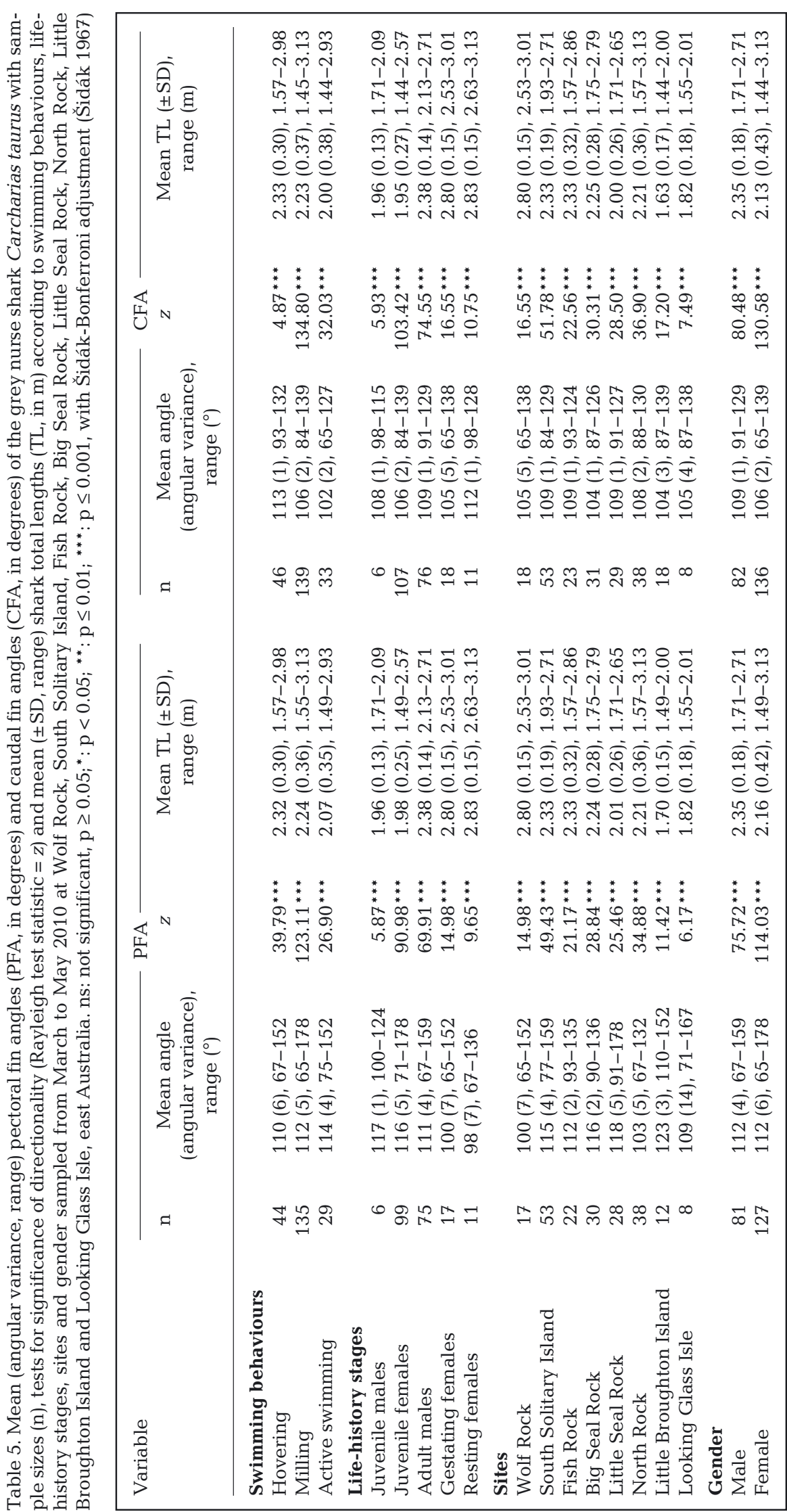

ming sharks used significantly more tail beats, but the caudal fin positions reflected those when milling with the fin held high. However, the range in dihedral angles was similar to that during hovering and contributed to ascent and descent as few turns were observed. Reduced TBF with increased TL during milling and active swimming suggested that the propulsive force generated by tail beats was greater in larger sharks. This may have resulted from the increased mass of aerobic red muscle for continuous swimming and anaerobic white muscle for burst swimming (Bone 1989, Shadwick \& Goldbogen 2012), and differing drag coefficients linked to denticle patterns (Gilligan \& Otway 2011) and/or smaller surface area to volume ratios.

Similarities and differences in swimming behaviour occurred among sites and life-history stages. Wolf Rock was occupied by gestating females that exhibited hovering and milling, with a greater frequency of hovering compared to all other sites except Fish Rock. Sharks spent the majority of time hovering in currents and/or milling near the seabed using their pectoral fins to maintain station. This low level of activity was likely adopted as maternal fasting occurs during the pre-parturition phase of gestation, facilitating energy conservation for the southerly migration in the late austral winter for parturition in spring in NSW waters (Bansemer \& Bennett 2009, Otway \& Ellis 2011).

Sharks inhabiting South Solitary Island, Fish Rock and Big Seal Rock comprised various life-history stages (adult males, resting females and juveniles) and exhibited low levels of activity as evidenced by hovering and milling. Furthermore, the mean dihedral angles indicated that sharks were holding their positions in the water column. The 
Table 6. Descriptions of the non-swimming behaviours of the grey nurse shark Carcharias taurus with life-history stages (LHS) (juvenile males: JM; juvenile females: JF; adult males: AM; gestating females: GF; resting females: RF; adult of unknown gender: $\mathrm{AU}$ ), shark total lengths (TL, in $\mathrm{m}$ ), durations (s), numbers of events per sequence and mean (angular variance, range) pectoral fin angles (PFA, in degrees) and caudal fin angles (CFA, in degrees) sampled from March to May 2010 at South Solitary Island (SS), Fish Rock (FR), Big Seal Rock (BS), Little Seal Rock (LS), North Rock (NR) and Little Broughton Island (LB), east Australia. (-) no data. Bold text denotes the same shark

\begin{tabular}{|c|c|c|c|c|c|c|c|c|}
\hline \multirow[t]{2}{*}{$\begin{array}{l}\text { Behaviour } \\
\text { (no. of sharks) }\end{array}$} & \multirow[t]{2}{*}{ Description } & \multirow[t]{2}{*}{ Site } & \multirow[t]{2}{*}{ LHS } & \multirow[t]{2}{*}{$\begin{array}{l}\mathrm{TL} \\
(\mathrm{m})\end{array}$} & \multirow[t]{2}{*}{$\begin{array}{c}\text { Duration } \\
(\mathrm{s})\end{array}$} & \multirow[t]{2}{*}{$\begin{array}{l}\text { Sequence } \\
\text { (no. of } \\
\text { events) }\end{array}$} & \multicolumn{2}{|c|}{$\begin{array}{c}\text { Mean angle } \\
\text { (angular variance) } \\
\text { range }\left({ }^{\circ}\right)\end{array}$} \\
\hline & & & & & & & PFA & CFA \\
\hline $\begin{array}{l}\text { Chafing } \\
\quad(\mathrm{n}=1)\end{array}$ & $\begin{array}{l}\text { Shark rolls and swims laterally so the } \\
\text { trunk and tail abrade the substrate }\end{array}$ & BS & JF & 1.62 & 13.2 & Yes (2) & - & $\begin{array}{r}96(4) \\
81-111\end{array}$ \\
\hline \multirow[t]{5}{*}{$\begin{array}{l}\text { Gill puff } \\
\qquad(\mathrm{n}=5)\end{array}$} & \multirow{5}{*}{$\begin{array}{l}\text { Gill slits widen briefly and usually } \\
\text { successively from the first gill slit. } \\
\text { Potentially analogous to mammalian } \\
\text { coughing }\end{array}$} & SS & $\mathbf{A M}$ & 2.3 & 9.6 & Yes (5) & $\begin{array}{l}110(3) \\
91-131\end{array}$ & $\begin{array}{r}95(1) \\
88-104\end{array}$ \\
\hline & & & $\mathrm{AM}$ & 2.29 & 0.6 & No & 99 & 106 \\
\hline & & FR & $\mathrm{AM}$ & 2.71 & 3 & Yes (2) & $\begin{array}{r}117(2) \\
107-126\end{array}$ & $\begin{array}{l}86(2) \\
75-96\end{array}$ \\
\hline & & BS & $\mathrm{JM}$ & 1.97 & 2.4 & Yes (2) & $\begin{array}{l}100(2) \\
91-109\end{array}$ & $\begin{array}{l}115(6) \\
97-134\end{array}$ \\
\hline & & NR & $\mathrm{JF}$ & 2.13 & 5.4 & Yes (3) & $\begin{array}{l}85(1) \\
78-91\end{array}$ & $\begin{array}{l}84(2) \\
72-95\end{array}$ \\
\hline \multirow[t]{4}{*}{$\begin{array}{l}\text { Head snapping } \\
\qquad(\mathrm{n}=4)\end{array}$} & \multirow{4}{*}{$\begin{array}{l}\text { Rapid, unilateral movement of the head } \\
\text { from and returning to the longitudinal } \\
\text { axis }\end{array}$} & SS & $\mathbf{A M}$ & 2.3 & 4.8 & Yes (2) & $\begin{array}{r}92(2) \\
84-101\end{array}$ & - \\
\hline & & FR & JF & 1.92 & 1.2 & No & - & 79 \\
\hline & & & $\mathrm{AM}$ & 2.58 & 0.6 & No & - & - \\
\hline & & BS & $\mathrm{AU}$ & 2.66 & 0.6 & No & - & 103 \\
\hline $\begin{array}{l}\text { Palatoquadrate } \\
\text { protrusion } \\
\quad(\mathrm{n}=1)\end{array}$ & $\begin{array}{l}\text { (1) Mandible depression, (2) cranium ele- } \\
\text { vation, (3) maxilla (palatoquadrate) pro- } \\
\text { trusion, (4) further cranium elevation and } \\
\text { maxilla retraction, (5) cranium depression } \\
\text { and completion of maxilla retraction and } \\
\text { (6) mandible elevation as cranium } \\
\text { depression concludes }\end{array}$ & SS & $\mathbf{A M}$ & 2.3 & 15.6 & Yes (3) & $\begin{array}{l}98(21) \\
58-144\end{array}$ & - \\
\hline \multirow{7}{*}{$\begin{array}{l}\text { Rapid withdrawal } \\
\quad(\mathrm{n}=7)\end{array}$} & \multirow{7}{*}{$\begin{array}{l}\text { Rapid departure of a shark away from a } \\
\text { disturbance, often incorporating a severe } \\
\text { turn }\end{array}$} & BS & JF & 1.81 & 1.8 & No & - & - \\
\hline & & LS & JF & 1.76 & 0.06 & No & - & 96 \\
\hline & & & JF & 1.68 & 0.06 & No & - & 85 \\
\hline & & NR & JF & 1.84 & 3 & No & - & 107 \\
\hline & & LB & JF & 1.5 & 0.06 & No & - & 141 \\
\hline & & & JF & 1.97 & 4.8 & No & 117 & 104 \\
\hline & & & $\mathrm{JF}$ & 1.6 & 0.6 & No & - & - \\
\hline \multicolumn{9}{|l|}{ Stand back } \\
\hline \multirow[t]{2}{*}{$(\mathrm{n}=2)$} & \multirow{2}{*}{$\begin{array}{l}\text { Simultaneous rapid withdrawal exhibited } \\
\text { by } 2 \text { oncoming sharks to avoid collision }\end{array}$} & LB & $\mathrm{JF}$ & 1.77 & 0.6 & No & - & 116 \\
\hline & & & JF & 1.56 & 6 & No & - & 125 \\
\hline
\end{tabular}

associated variances and range were less than when hovering and milling (pooled across all sites), indicating that changes in direction were less pronounced and providing further evidence of minimal energy expenditure. Previous research (Otway \& Ellis 2011) showed that adult male grey nurse sharks punctuate their annual northerly migration with occupation of these and other sites for varying durations. Whilst at these sites, it is likely that adult males were optimising energy use, as has previously been documented for scalloped hammerhead sharks Sphyrna lewini aggregated around a seamount (Klimley \& Nelson 1984). Similarly, resting female sharks at Fish Rock and Big Seal Rock would have been replenishing energy stores expended during their previous pregnancy. It is probable that the low levels of activity exhibited by resting females were adopted to conserve energy for reproduction and the associated migration to gestation sites off QLD (Bansemer \& Bennett 2009).

Little Broughton Island is a highly dynamic site characterised by complex bottom topography with narrow gutters and crevices, variable currents, surge from breaking waves reaching the shallow seabed and expanses of kelp across much of the substratum. This habitat is typical of the shallow, inshore rocky 
reefs found along the NSW coast (Underwood et al. 1991) and is used for substantial periods of time by juvenile grey nurse sharks (Otway \& Ellis 2011). The occupation of similar habitats occurs in juvenile grey nurse (ragged-tooth) sharks off the eastern cape of South Africa (Bass et al. 1975, Smale 2002, Dicken et al. 2006). Only juvenile sharks were observed at Little Broughton Island, and, whilst they mainly exhibited milling, the greater frequency of active swimming and the larger TBF suggested a greater level of activity at this site. The mean dihedral angle was greater than that at other sites, with the reduced range and variance likely due to the fins being held in a more consistent position to maintain station (sensu Wilga \& Lauder 2000, Maia et al. 2012) or counteract downward forces exerted by the surge of breaking waves.

Little Seal Rock, North Rock and Looking Glass Isle were predominantly occupied by juvenile sharks that exhibited mainly milling. The range in dihedral angles suggested pectoral fins were used for turning and maintaining position. The low-activity swimming behaviours exhibited at these sites further suggested that the sharks expended minimal energy during daylight hours.

\section{Grey nurse shark non-swimming behaviours}

Grey nurse sharks use active (buccal pumping) and passive (ram) ventilation depending on their respiratory needs and swimming behaviour (Otway et al. 2009). Whilst most sharks in the current study exhibited ram ventilation, those that used buccal pumping had rates of 20 to 21 buccal pumps min $^{-1}$, similar rates to those documented by Barker et al. (2011) at Fish Rock and Magic Point off Sydney, NSW.

Other non-swimming behaviours comprising chafing, palatoquadrate protrusion, head snapping, gill puff, rapid withdrawal and stand back (Myrberg \& Gruber 1974, Compagno 2001, Martin 2007) were infrequently observed. Non-swimming behaviours were mainly exhibited by juvenile sharks and occurred across 6 sites. Chafing was achieved by altering the PFA (Wilga \& Lauder 2000, Maia et al. 2012) and was probably done to remove external parasites. This grooming behaviour has been recorded for captive bonnethead sharks $S$. tiburo and lemon sharks Negaprion brevirostris (Myrberg \& Gruber 1974) and in grey nurse sharks at Julian Rocks off Byron Bay, NSW (Hayward 2003).

A behavioural sequence incorporating palatoquadrate protrusion, gill puff and head snapping occurred distant from the divers with the USVPS and in the absence of prey (i.e. not feeding behaviour). It was likely used to realign cartilaginous jaw elements and therefore should be categorised as grooming behaviour. Similar palatoquadrate protrusion events and sequences have been observed in non-feeding Caribbean reef sharks (Carcharhinus perezi; Ritter 2008). The isolated gill puff events and sequences observed were probably grooming behaviours to clear the orobranchial cavity of debris as previously observed in semi-captive bonnethead sharks (Myrberg \& Gruber 1974). A further 2 head-snapping events occurred and were also likely grooming behaviour, possibly to reposition cartilaginous elements or remove debris, or they may have been involuntary muscular contractions as documented in captive grey nurse sharks and sandbar sharks C. plumbeus (Hannon \& Crook 2004). Another gill puff immediately followed by a brief switch to active swimming was likely elicited by 3 camera flashes in quick succession, and, in this context, the behaviour was considered a 'flight' response and categorised as agonistic behaviour (Martin 2007).

Rapid withdrawal events accounted for $36.8 \%$ of the non-swimming behaviours. Four rapid withdrawal events were preceded by investigative approaches to the USVPS and diver, whereas another was probably elicited by a diver approaching the shark. These events should be categorised as agonistic behaviour as they represented 'flight' responses to identified stimuli and, together with the agonistic gill puff, accounted for $<0.1 \%$ of the total observation time. Similar rapid withdrawals ('flight' responses) have been observed in grey reef sharks C. amblyrhynchos by Johnson \& Nelson (1973) and were often followed by further agonistic ('fight'/threat) displays. In contrast, grey nurse sharks did not follow any rapid withdrawal with aggressive/threatening displays. Another rapid withdrawal occurred when exhaled air bubbles from a diver made contact with a shark, a 'flight' response also observed in aggregated scalloped hammerhead sharks (Klimley 1981/1982). Additionally, the frequency of rapid withdrawals by juvenile sharks was similar to behavioural observations of small bonnethead, lemon, silky (C. falciformis) and reef $(C$. springeri) sharks compared with their larger conspecifics (Myrberg \& Gruber 1974).

During stand back, 2 approaching sharks turned simultaneously and retreated to avoid collision and did not exhibit any other non-swimming behaviours immediately thereafter. Similarly, a shark exhibited rapid withdrawal to avoid collision when surge forced the shark close to the rock wall of a shark gut- 
ter. Neither event was associated with threatening displays and merely represented extended swimming behaviour. Rapid withdrawal and stand back have previously been classified as agonistic behaviours (Martin 2007), but both could have been categorised as swimming or agonistic behaviour in this study. To eliminate future ambiguity, rapid withdrawal and stand back behaviours exhibited during navigation should be categorised as a swimming behaviour and referred to as collision avoidance. This would permit the continued use of stand back and rapid withdrawal as types of agonistic behaviour. These results also highlighted the importance of identifying the stimuli that elicit behaviours and the use of appropriate terminology when describing, defining, and/or categorising the behaviours of sharks and other animals.

\section{Scuba diving tourism impacts on grey nurse shark behaviour}

Underwater visual observations have previously been used to assess the potential impacts of scuba diving tourism on grey nurse shark behaviour at sites off eastern Australia (Smith et al. 2010, 2014, Barker et al. 2011). The first study at Fish Rock (Smith et al. 2010) documented a significant decrease in milling behaviour when $>6$ divers were present and a high rate of diver compliance with management guidelines (code of conduct and relevant legislation). The second study at Magic Point off Sydney, NSW (Barker et al. 2011) reported significantly greater swimming rates when 12 divers simultaneously approached to within $3 \mathrm{~m}$ of the sharks. By acting in this way, divers breached the code of conduct as the group exceeded 10 divers, interrupted the sharks' swimming patterns and trapped them within the entrance to a cave. A study at Wolf Rock, Julian Rocks, South Solitary Island and Fish Rock (Smith et al. 2014) found no significant changes to grey nurse shark swimming behaviour irrespective of diver numbers, distances to the sharks, or complete compliance by divers with management guidelines.

Putative agonistic pectoral fin depression (i.e. a 'fight' response) following approaches by scuba divers has been reported using visual observations of grey nurse sharks at Fish Rock (Barker et al. 2011) and sandtiger (grey nurse) sharks at 2 wrecks off North Carolina, USA (Martin 2007). These observations are contrary to numerous reports of this species as docile (e.g. Compagno 2001, EA 2002, Otway \& Ellis 2011). Confirming the existence of this threa- tening, non-swimming behaviour requires accurate quantification of pectoral fin positions (angles) during interactions with tourist divers. The USVPS used in this study enabled the PFA and other components of behaviour (e.g. TBF, ROM, CFA, and nonswimming behaviours) to be accurately quantified in the absence of tourist divers. This partial ethogram can be used as a baseline for cost-effective and efficacious assessments of scuba diving tourism impacts on grey nurse shark behaviour. Future research using stereo-photogrammetry at these and other aggregation sites will enable behavioural changes to be documented and determine the need for alterations to current management strategies to facilitate the ongoing sustainability of scuba diving tourism with this species.

Acknowledgements. This work was done whilst K.R.S. was in receipt of an Australian Postgraduate Award and funding from Victoria University and the NSW Department of Primary Industries (DPI). The research was conducted under a scientific research permit (NSW DPI: P01/0059[A]-2.0) and animal research ethics committee approval (NSW DPI: ACEC 99/14 Port Stephens). The constructive comments provided by 2 anonymous reviewers and the editor enhanced the manuscript. We thank J. Seager of @SeaGIS for his invaluable support with using EventMeasure, J. Gilligan for his assistance in the field and G. West for his help with the figures.

\section{LITERATURE CITED}

Ahonen H, Harcourt RJ, Stow AJ (2009) Nuclear and mitochondrial DNA reveals isolation of imperilled grey nurse shark populations (Carcharias taurus). Mol Ecol 18: 4409-4421

Altmann J (1974) Observational study of behaviour: sampling methods. Behaviour 49:227-267

Bansemer CS, Bennett MB (2009) Reproductive periodicity, localised movements and behavioural segregation of pregnant Carcharias taurus at Wolf Rock, southeast Queensland, Australia. Mar Ecol Prog Ser 374:215-227

> Barker SM, Peddemors VM, Williamson JE (2011) A video and photographic study of aggregation, swimming and respiratory behaviour changes in the grey nurse shark (Carcharias taurus) in response to the presence of scuba divers. Mar Freshw Behav Physiol 44:75-92

Bass AJ, D'Aubrey JD, Kistnasamy N (1975) Sharks of the east coast of southern Africa. IV. The families Odontaspididae, Scapanorhynchidae, Isuridae, Cetorhinidae, Alopiidae, Orectolobidae, and Rhiniodontidae: investigational report No. 39. The Oceanographic Research Institute, Durban

Batschelet E (1981) Circular statistics in biology. Academic Press, London

Bone Q (1989) Muscles and locomotion. In: Shuttleworth TJ (ed) Physiology of elasmobranch fishes. Springer-Verlag, Berlin, p 99-141

Bonnet X, Shine R, Lourdais O (2002) Taxonomic chauvinism. Trends Ecol Evol 17:1-3 
Bres M (1993) The behaviour of sharks. Rev Fish Biol Fish 3:133-159

Bruce BD, Stevens JD, Bradford RW (2005) Designing protected areas for grey nurse sharks off eastern Australia: final report. Commonwealth of Australia, Hobart, TAS

Brunnschweiler JM, Barnett A (2013) Opportunistic visitors: long-term behavioural response of bull sharks to food provisioning in Fiji. PLoS ONE 8:e58522

Brunnschweiler JM, Queiroz N, Sims DW (2010) Oceans apart? Short-term movements and behaviour of adult bull sharks Carcharhinus leucas in Atlantic and Pacific Oceans determined from pop-off satellite archival tagging. J Fish Biol 77:1343-1358

Cavanagh RD, Kyne PM, Fowler SL, Musick JA, Bennett MB (eds) (2003) The conservation status of Australasian Chondrichthyans: report of the IUCN Shark Specialist Group Australia and Oceania Regional Red List Workshop. The University of Queensland, Brisbane, QLD

Compagno LJV (2001) Sharks of the world. An annotated and illustrated catalogue of shark species known to date, Vol 2. Bullhead, mackerel and carpet sharks (Heterodontiformes, Lamniformes and Orectolobiformes). Food and Agriculture Organization of the United Nations, Rome

Cubero-Pardo P, Herrón P, González-Pérez F (2011) Shark reactions to scuba divers in two marine protected areas of the eastern tropical Pacific. Aquat Conserv 21:239-246

> Dans SL, Degrati M, Pedraza SN, Crespo EA (2012) Effects of tour boats on dolphin activity examined with sensitivity analysis of Markov chains. Conserv Biol 26:708-716

De Sapio R (1976) Calculus for the life sciences. W. H. Freeman and Company, San Francisco, CA

> Dicken ML, Smale MJ, Booth AJ (2006) Spatial and seasonal distribution patterns of the ragged-tooth shark Carcharias taurus along the coast of South Africa. Afr J Mar Sci 28:603-616

> Durbin J, Watson GS (1950) Testing for serial correlation in least squares regression. I. Biometrika 37:409-428

$>$ Durbin J, Watson GS (1951) Testing for serial correlation in least squares regression. II. Biometrika 38:159-178

EA (Environment Australia) (2002) Recovery plan for the grey nurse shark (Carcharias taurus) in Australia. Commonwealth of Australia, Canberra, ACT

Farebrother RW (1980) Algorithm AS 153: Pan's procedure for the tail probabilities of the Durbin-Watson statistic. J R Stat Soc Ser C Appl Stat 29:224-227

- Francis MP (2006) Morphometric minefields - towards a measurement standard for chondrichthyan fishes. Environ Biol Fishes 77:407-421

Gilligan JJ, Otway NM (2011) Comparison of dorsal and pectoral fin denticles for grey nurse, great white, and six whaler sharks from east Australian waters. J Proc R Soc New South Wales 144:66-82

Gilmore RG, Dodrill JW, Linley PA (1983) Reproduction and embryonic development of the sand tiger shark, Odontaspis taurus (Rafinesque). Fish Bull 81:201-225

> Goldman KJ, Branstetter S, Musick JA (2006) A re-examination of the age and growth of sand tiger sharks, Carcharias taurus, in the western North Atlantic: the importance of ageing protocols and use of multiple back-calculation techniques. Environ Biol Fishes 77:241-252

> Gordon I (1993) Pre-copulatory behaviour of captive sandtiger sharks, Carcharias taurus. Environ Biol Fishes 38: 159-164

Gruber SH, Nelson DR, Morrissey JF (1988) Patterns of activity and space utilization of lemon sharks, Negaprion brevirostris, in a shallow Bahamian lagoon. Bull Mar Sci 43:61-76

Guttridge TL, Gruber SH, Gledhill KS, Croft DP, Sims DW, Krause J (2009) Social preferences of juvenile lemon sharks, Negaprion brevirostris. Anim Behav 78:543-548

Hannon GE, Crook AC (2004) Observations of the behaviour of captive sand tiger sharks, Carcharias taurus (Rafinesque, 1810). Drum and Croaker, Spec Edn, p 51-61

Hayward A (2003) Observations of grey nurse shark (Carcharias taurus) and scuba diver behaviour. Honours thesis, Southern Cross University, Lismore, NSW

> Heithaus MR, Dill LM, Marshall GJ, Buhleier B (2002) Habitat use and foraging behaviour of tiger sharks (Galeocerdo cuvier) in a seagrass ecosystem. Mar Biol 140: $237-248$

Henningsen AD, Smale MJ, Gordon I, Garner R, MarinOsorno R, Kinnunen N (2004) Captive breeding and sexual conflict in elasmobranchs. In: Smith M, Warmolts D, Thoney D, Heuter R (eds) The elasmobranch husbandry manual: captive care of sharks, rays and their relatives. Ohio Biological Survey, Columbus, $\mathrm{OH}$, p 237-248

> Heyman WD, Graham RT, Kjerfve B, Johannes RE (2001) Whale sharks Rhincodon typus aggregate to feed on fish spawn in Belize. Mar Ecol Prog Ser 215:275-282

Jennions MD, Møller AP (2003) A survey of the statistical power of research in behavioural ecology and animal behaviour. Behav Ecol 14:438-445

Johnson RH, Nelson DR (1973) Agonistic display in the gray reef shark, Carcharhinus menisorrah, and its relationship to attacks on man. Copeia 1973:76-84

Klimley AP (1981/1982) Grouping behaviour in the scalloped hammerhead. Oceanus 24:65-71

Klimley AP, Nelson DR (1984) Diel movement patterns of the scalloped hammerhead shark (Sphyrna lewini) in relation to El Bajo Espiritu Santo: a refuging central-position social system. Behav Ecol Sociobiol 15:45-54

Kohler NE, Casey JG, Turner PA (1998) NMFS Cooperative shark tagging program, 1962-93: an atlas of shark tag and recapture data. Mar Fish Rev 60:1-87

> Laroche RK, Kock AA, Dill LM, Oosthuizen WH (2007) Effects of provisioning ecotourism activity on the behaviour of white sharks Carcharodon carcharias. Mar Ecol Prog Ser 338:199-209

Last PR, Stevens JD (2009) Sharks and rays of Australia, 2nd edn. CSIRO Publishing, Collingwood, VIC

Lincoln Smith M, Roberts C (2010) Development and implementation of a population estimation protocol to provide an estimate of east coast population numbers for grey nurse sharks (Carcharias taurus): prepared for the Department of the Environment, Water, Heritage and the Arts. Cardno Ecology Lab, Brookvale, NSW

Lundquist D, Sironi M, Würsig B, Rowntree V, Martino J, Lundquist L (2013) Response of southern right whales to simulated swim-with-whale tourism at Península Valdés, Argentina. Mar Mamm Sci 29:E24-E45

Lusseau D, Higham JES (2004) Managing the impacts of dolphin-based tourism through the definition of critical habitats: the case of bottlenose dolphins (Tursiops spp.) in Doubtful Sound, New Zealand. Tour Manag 25: $657-667$

Maia AMR, Wilga CAD, Lauder GV (2012) Biomechanics of locomotion in sharks, rays, and chimaeras. In: Carrier J, Musick J, Heithaus M (eds) Biology of sharks and their relatives, 2nd edn. CRC Press, Boca Raton, FL, p 125-151 
Mann J (1999) Behavioural sampling methods for cetaceans: a review and critique. Mar Mamm Sci 15:102-122

Martin RA (2007) A review of shark agonistic displays: comparison of display features and implications for sharkhuman interactions. Mar Freshw Behav Physiol 40:3-34

Miller LJ, Kuczaj S, Herzing D (2011) Stereotypic behaviour in wild marine carnivores? Zoo Biol 30:365-370

Mollet HF, Cailliet GM (2002) Comparative population demography of elasmobranchs using life history tables, Leslie matrices and stage-based matrix models. Mar Freshw Res 53:503-516

Myrberg AA, Gruber SH (1974) The behaviour of the bonnethead shark, Sphyrna tiburo. Copeia 1974:358-374

Ord TJ, Martins EP, Thakur S, Mane KK, Börner K (2005) Trends in animal behaviour research (1968-2002): ethoinformatics and the mining of library databases. Anim Behav 69:1399-1413

> Otway NM, Ellis MT (2011) Pop-up archival satellite tagging of Carcharias taurus: movements and depth/temperature-related use of south-eastern Australian waters. Mar Freshw Res 62:607-620

> Otway NM, Bradshaw CJA, Harcourt RG (2004) Estimating the rate of quasi-extinction of the Australian grey nurse shark (Carcharias taurus) population using deterministic age- and stage-classified models. Biol Conserv 119: 341-350

Otway NM, Louden BM, Storrie MT, Gilligan JJ (2008) Construction of an underwater photogrammetry system for quantifying the population size-structure and rates of mortality of the critically endangered grey nurse shark in SE Australian waters. NSW Department of Primary Industries, Nelson Bay, NSW

Otway NM, Storrie MT, Louden BM, Gilligan JJ (2009) Documentation of depth-related migratory movements, behaviour movements at critical habitat sites and the effects of scuba diving for the east coast grey nurse shark population: Fisheries Final Report Series. Industry \& Investment NSW, Nelson Bay, NSW

Pierce SJ, Méndez-Jiménez A, Collins K, Rosero-Caicedo M, Monadjem A (2010) Developing a code of conduct for whale shark interactions in Mozambique. Aquat Conserv 20:782-788

Pratt HL Jr, Carrier JC (2001) A review of elasmobranch reproductive behaviour with a case study on the nurse shark, Ginglymostoma cirratum. Environ Biol Fishes 60:157-188

Quiros AL (2007) Tourist compliance to a code of conduct and the resulting effects on whale shark (Rhincodon typus) behaviour in Donsol, Philippines. Fish Res 84:102-108

Ritter EK (2008) Mouth gaping behaviour in Caribbean reef sharks, Carcharhinus perezi. Mar Freshw Behav Physiol 41:161-167

Shadwick RI, Goldbogen JA (2012) Muscle function and swimming in sharks. J Fish Biol 80:1904-1939
Shortis MR, Harvey ES (1998) Design and calibration of an underwater stereo-video system for the monitoring of marine fauna populations. Int Arch Photogramm Remote Sens 32:792-799

Šidák Z (1967) Rectangular confidence regions for the means of multivariate normal distributions. J Am Stat Assoc 62:626-633

Smale MJ (2002) Occurrence of Carcharias taurus in nursery areas of the Eastern and Western Cape, South Africa. Mar Freshw Res 53:551-556

Smith K, Scarr M, Scarpaci C (2010) Grey nurse shark (Carcharias taurus) diving tourism: tourist compliance and shark behaviour at Fish Rock, Australia. Environ Manag 46:699-710

Smith KR, Scarpaci C, Scarr MJ, Otway NM (2014) Scuba diving tourism with critically endangered grey nurse sharks (Carcharias taurus) off eastern Australia: tourist demographics, shark behaviour and diver compliance. Tour Manag 45:211-225

Stevens JD, Bradford RW, West GJ (2010) Satellite tagging of blue sharks (Prionace glauca) and other pelagic sharks off eastern Australia: depth behaviour, temperature experience and movements. Mar Biol 157:575-591

Stow A, Zenger K, Briscoe D, Gillings M, Peddemors V, Otway N, Harcourt R (2006) Isolation and genetic diversity of endangered grey nurse shark (Carcharias taurus) populations. Biol Lett 2:308-311

Talbot B, Molloy S, Chapman R, Riches M (2004) The rivers to the sea: experiences with two endangered aquatic fish species. In: Hutchings P, Lunney D, Dickman C (eds) Threatened species legislation: Is it just an Act? Royal Zoological Society of New South Wales, Sydney, NSW, p 125-134

Underwood AJ (1997) Experiments in ecology. Cambridge University Press, Cambridge

Underwood AJ, Kingsford MJ, Andrew NL (1991) Patterns in shallow subtidal marine assemblages along the coast of New South Wales. Aust J Ecol 16:231-249

Werry JM, Lee SY, Lemckert CJ, Otway NM (2012) Natural or artificial? Habitat-use by the bull shark, Carcharhinus leucas. PLoS ONE 7:e49796

> Werry JM, Planes S, Berumen ML, Lee KA, Braun CD, Clua E (2014) Reef-fidelity and migration of tiger sharks, Galeocerdo cuvier, across the Coral Sea. PLoS ONE 9:e83249

Whitney NM, Pratt HL, Carrier JC (2004) Group courtship, mating behaviour and siphon sac function in the whitetip reef shark, Triaenodon obesus. Anim Behav 68: 1435-1442

> Wilga CD, Lauder GV (2000) Three-dimensional kinematics and wake structure of the pectoral fins during locomotion in leopard sharks Triakis semifasciata. J Exp Biol 203: 2261-2278

Submitted: May 6, 2014; Accepted: September 26, 2014 Proofs received from author(s): December 23, 2014
Editorial responsibility: Robert Harcourt, Sydney, Australia 